\title{
Scenario of Public Participation in Assembly Elections of Jammu \& Kashmir: A Study (1962-2008)
}

\author{
Ramesh Pandita \\ BGSB University, Jammu - 180013, Rajouri, Jammu \& Kashmir, India \\ E-mail address: rameshpandita90@gmail.com
}

\begin{abstract}
The present study is an attempt to evaluate the prevailing democracy in Jammu \& Kashmir, India which is also being termed as conflict zone in South Asia. The study analyzes elections held to state legislator during the period 1962-2008. Aspects like, participation of national and local political parties has been evaluated, participation and performance of some prominent political parties, representation given to women candidates, participation of electorate etc have been studied.
\end{abstract}

Keywords: Jammu \& Kashmir; India; Elections; State legislator; Assembly Elections; Electorate

\section{INTRODUCTION}

Public participation in the electoral process of any given nation not just reflects the prevalence of democracy in that very country but also guarantees of securing and protecting the interests of its citizens. Govt by the people of the people and for the people is the true hymn of democracy which still resonate a fresh in the ears and minds of one and all across the length and breadth of the world ${ }^{[1]}$. Democracy equally stands about advocacy and prevalence of secular ideas and practices, whereby citizens of country have freedom to practice religion, perform social \& cultural practices, without barriers of colour and language, and to participate in socio economic activities of nation without any fear or favour.

India is known as one of the world's largest democracy, having over 1.2 billion people, having federal structure of governance where by Union of India is seen as composition of 35 union territories and sates ${ }^{[2]}$. The presence of democratic values and believing in the same get reflected form the very beginning of the pre and post independence era of India, whereby most of the states became the part of the union of India by signing accession document thereby confirming of their becoming the part of union of India of their free will, without any fear or favour.

The state of Jammu and Kashmir became the part of the Union of India by signing the same accession document which rest of the states signed. Though it is believed that the accession document was signed by the then Maharaja of the state out of compulsion but without any doubt was an irreversible process and irrevocable decision. Though the decision taken by the then ruler of the state was timely and in the best interest of the people of Jammu \& Kashmir, but the few vested interests both from within and outside the state who neither lived the 
accession era nor witnessed the circumstances under which the decision was taken, term the decision against their wishes and aspirations. Given this fact the state of Jammu \& Kashmir is being termed as conflict zone in the South Asia.

In the present study evaluation has been made of the electoral process held in the state of Jammu \& Kashmir since its becoming the part of Union of India. The study revolves round the 9 assembly elections held in the state of Jammu \& Kashmir during the period 1962-2008. The study is also timely for the fact that Jammu \& Kashmir state is due to undergo $10^{\text {th }}$ assembly election by the end 2014 or beginning of 2015 .

\section{BRIEF ABOUT JAMMU \& KASHMIR}

Jammu \& Kashmir like rest of the states of the Union of India acceded to it by signing an accession document on October 26, 1947, as such has since then become an integral part of the country ${ }^{[3]}$. Geographically the state is located in the northern part of the Indian subcontinent and is spread over 101,387 square $\mathrm{km}$. As per the latest population census of Union of India undertaken in the year 2011, the state of Jammu \& Kashmir is having population of 1,25,48,926 persons with literacy rate of $68.70 \%$. In terms of population density, the state is ranked at $28^{\text {th }}$ place among all the 35 states and union territories of the county by having 124 persons per square $\mathrm{km}$, which is an increase of 24 persons from the last decade ${ }^{[4]}$. The state of Jammu \& Kashmir shares international border from three sides with countries like Pakistan and Afghanistan from western side, China \& Tibet from north eastern side. Punjab and Himachal Pradesh are the only two state of India sharing boarders with Jammu \& Kashmir and is also the lone corridor which connects the state with rest of the country. The state of Jammu \& Kashmir has a natural geographical divide, the topology of state makes it abode of thee different regions namely, Jammu, Kashmir and Ladakh, with each region having unique cultural, linguistic and social diversity, even the regions have three different temperate zones.

\section{COMPOSITION OF JAMMU \& KASHMIR ASSEMBLY}

The assembly of Jammu \& Kashmir is bicameral in nature consisting of Governor and two houses, known as Legislative Council (Upper House) and Legislative Assembly (Lower House), which more or less work on the pattern of Indian parliament viz., Rajya Sabha and Lok Sabha. Legislative Assembly consists of 111 members out of which 24 seats remain vacant for being reserved for the Pakistan part of Kashmir and 87 go for direct elections. Earlier there were 100 seats but were later increased to 111 seats by 20th amendment Act 1988 of Jammu \& Kashmir Constitution ${ }^{[5]}$. Legislative Council has strength of 36 members to which 11 members each are elected from Kashmir and Jammu region 8 members are nominated by Governor, and rest of the members represent municipal councils and Panchayats of state ${ }^{[6]}$.

\section{REVIEW OF LITERATURE}

Political and other social scientists have undertaken various studies on the democracies and the democratic process of various countries on range of issues depending upon the individual interest of each social scientist. Studying electoral process of a particular country or federal state apart from giving an insight about the public participation in democratic exercise 
do help in seeking solution to existing issues which have direct bearing on the electoral process of that particular nation. Some of the studies undertaken earlier by social scientists have been reviewed hereunder to give better understanding of the subject.

Shastri (2014) ${ }^{[7]}$ in his study assessed the outcome of Karnataka Assembly elections held during the year 2013. The researcher is of the view that the Karnataka poll was more an unequivocal indictment against the existing government and rated the congress victory more an anti-incumbency factor rather the pro-congress vote. The author also remarked that individual perception of elector towards contesting parties is what makes one to caste vote to a particular party.

Miwa (1997) ${ }^{[08]}$ undertook study on the 1996 general election of India in which BJP emerged the single largest party by bagged as many as 161 seats with a gain of 41 seats from corresponding elections. BJP pushed the old political war horse of the country INC to second place which just managed to secure only 140 seats, short of 104 seats from its previous performance. The researcher dubbed this period as phase of economic liberalization for India as emphasis was laid on the devaluation of rupee to boost trade and seek finances from global funding agencies like IMF and World Bank. Lean and Gerring (2013) ${ }^{[9]}$ studied 2011 general elections of Liberia, which has two tier electoral process in 15 counties having presidential form of governance, chosen for a period of six years. The researcher made that $76.12 \%$ voter turnout was recorded during that particular election in which 16 parties were in fray. Mueller and Dardanelli (2013) ${ }^{[10]}$ studied parliamentary elections of Switzerland held during the year 2011 and dubbed the elections as historical as two decade old political practices came to an end and heralded a new political era in the country.

Tinker and Walker (1956) ${ }^{[11]}$ analyzed the first general elections of India and observed that the outcome of the elections was somewhat on expected lines as INC emerged the single largest party by bagging as many as $74.43 \%$ seats with $45.10 \%$ vote share. Researchers also took note that the elections in country were held on the lines of British electoral process and owed the credit for successful conduct of the elections in India to Election Commission of India which within two years of its establishment made general elections in the country possible with their entire efficiency. Kothari R (1967) ${ }^{[12]}$ while writing on the Indian polity refereed congress as the stronghold in country's politics and denoted the existence of congress rule in country as strongest and powerful where multiparty system of the country has to fight with Congress System.

Kaviraj (2007) ${ }^{[13]}$ studied the general elections of India and made observations about the declining vote share percentage of congress to $34.3 \%$ in 1977 from $47.8 \%$ in 1957 , except for the year 1984 when the congress secured $48.1 \%$ vote share. The rising percentage of vote share by party in 1984 is owed to the death of Smt. Indira Gandhi, the powerful women politician in the history of Indian polity with no parallels till date nor is expected the emergence of any other women face in near future which may even come closer to her powerful persona. Kumar (2002) ${ }^{[14]}$ in his work referred the need to reform Indian electoral process.

Minal (2009) ${ }^{[15]}$ in her study showed concerns about the meager women representation in the Maharashtra assembly despite the increase in the women contestants from 16 in 1952 to 157 in 2004 during which 5 and 12 women candidates succeeded in the respective elections. Maximum 247 women candidates contested 1995 elections in Maharashtra, while as maximum of 19 women candidates were represented in the Maharashtra assembly in the year in 1980

Karlheinz (2013) ${ }^{[16]}$ studied European elections held during the year 1979 and 1984, wherein 1984 elections proved a test in domestic politics as both pro and anti government parties lost the elections badly. Abramson et al (2013) ${ }^{[17]}$ undertook study on voting rules on of British general elections held in the year 2010 which are regarded as historical for resulting 
hung parliament in Britain after generations. Haughton and Kar-Sovec (2013) ${ }^{[18]}$ studied 2011 general elections of Slovenia and highlighted the role of smaller political parties and the part they play in formation of government especially in prevailing coalition era. The researchers further observed that how people are growing conscious of their fundamental right and are overthrowing incompetent and corrupt politicians. The other observations made by the researchers were about the finding of place by new entrants in politics on just and genuine issues if raised aptly. This also gets corroborated by the recent results of the Delhi assembly elections of 2014 in which new entrant 'Aam Aadmi Party' bagged 28 seats out of total seventy seats and also formed the government with the help of congress. The party entered into politics with genuine issues and the electorate of Delhi equally responded the manifesto of party by putting it into power.

\section{OBJECTIVES OF THE STUDY}

- To study the existence of democratic setup in the state of Jammu \& Kashmir under Indian rule which is being referred as conflict zone in South Asia by certain sections both within and outside the state, by terming the state as devoid of prevalence of democracy.

- To assess the growth and distribution of both national and local political parties in the state of Jammu \& Kashmir since the elections held to first state legislator and the existence of some of prominent political parties in state by evaluating their performance

- The other aspects undertaken in the study include growth of both male and female contestants from each corresponding election, success percentage and women representatives in each general election, deposits forfeited by women candidates on election to election basis and many other similar aspects.

- To study the growth and participation of electorate of state in each election held to state legislator

\section{SCOPE AND METHODOLOGY}

The present study is purely based on analysis undertaken over secondary data retrieved from the official website of the Election Commission of India on October 30, 2013, accessible at http://eci.gov.in/eci_main1/ElectionStatistics.aspx. The data retrieved was totally in raw form as such was put to structuration before analysis, keeping in view the objectives of the study. Various statistical tools and techniques were used to analyze the data. To perform simple operations like addition, subtraction, multiplication, division and drawing percentage etc. MS excel was used. On the similar lines study can be undertaken in different states of the union of India, where by better understanding can be developed about the regional and national aspiration of the people of country. The study can help to understand the existing loop holes in the state polity of Jammu \& Kashmir, which is not being deemed as people centric and is being equally seen as the reason whereby people of state especially from Kashmir region have waged freedom struggle with the union of India despite their active participation in the democratic process of the country, be it in the general elections or assembly elections. 


\section{DISCUSSION AND DATA ANALYSIS}

Although the statistical figures reflected in the tables drawn and the graphical representation given at few places are self explanatory about the various aspects of the state politics of Jammu \& Kashmir, but still to present a clear idea about various facets of the sate polity brief discussion has been added against each table. Percentage at most places has been drawn up to two decimal places, also the percentage has not been rounded off as such may not exactly reflect the $100 \%$ mark at few places.

Table I. Distribution \& Growth of Parties in State Elections.

\begin{tabular}{|c|c|c|c|c|c|c|}
\hline Year & Seats & $\begin{array}{c}\text { National } \\
\text { Parties } \\
(\%)\end{array}$ & $\begin{array}{c}\text { State Parties } \\
\text { (Local) } \\
\text { Independents } \\
(\%)\end{array}$ & $\begin{array}{c}\text { State } \\
\text { Parties } \\
\text { (Non- } \\
\text { Local) }\end{array}$ & Total & $\begin{array}{c}\text { Corresponding } \\
\text { Growth (\%) }\end{array}$ \\
\hline $\mathbf{1 9 6 2}$ & 75 & - & $6(100)$ & - & 6 & - \\
\hline $\mathbf{1 9 6 7}$ & 75 & $4(57.14)$ & $3(42.86)$ & - & 7 & $1(16.66)$ \\
\hline $\mathbf{1 9 7 2}$ & 75 & $6(75.00)$ & $2(25.00)$ & - & 8 & $1(14.28)$ \\
\hline $\mathbf{1 9 7 7}$ & 76 & $3(50.00)$ & $3(50.00)$ & - & 6 & $-2(-25.00)$ \\
\hline $\mathbf{1 9 8 3}$ & 76 & $6(60.00)$ & $4(40.00)$ & - & 10 & $4(66.66)$ \\
\hline $\mathbf{1 9 8 7}$ & 76 & $7(63.63)$ & $4(36.37)$ & - & 11 & $1(10.00)$ \\
\hline $\mathbf{1 9 9 6}$ & 87 & $6(50.00)$ & $6(50.00)$ & - & 12 & $1(9.09)$ \\
\hline $\mathbf{2 0 0 2}$ & 87 & $6(28.57)$ & $10(47.61)$ & $5(23.80)$ & 21 & $9(75.00)$ \\
\hline $\mathbf{2 0 0 8}$ & 87 & $7(16.27)$ & $3(6.97)$ & $33(76.74)$ & 43 & $22(104.76)$ \\
\hline Avg & & $45(36.29)$ & $41(33.06)$ & $38(30.64)$ & 13.77 & $37(30.16)$ \\
\hline
\end{tabular}

After acceding to the Union of India, the first assembly elections were held in the state of Jammu \& Kashmir in the year 1962 by contesting election on as many as 75 seats. So far the state of Jammu \& Kashmir has gone through 9 assembly elections, which can be divided into three legs. 


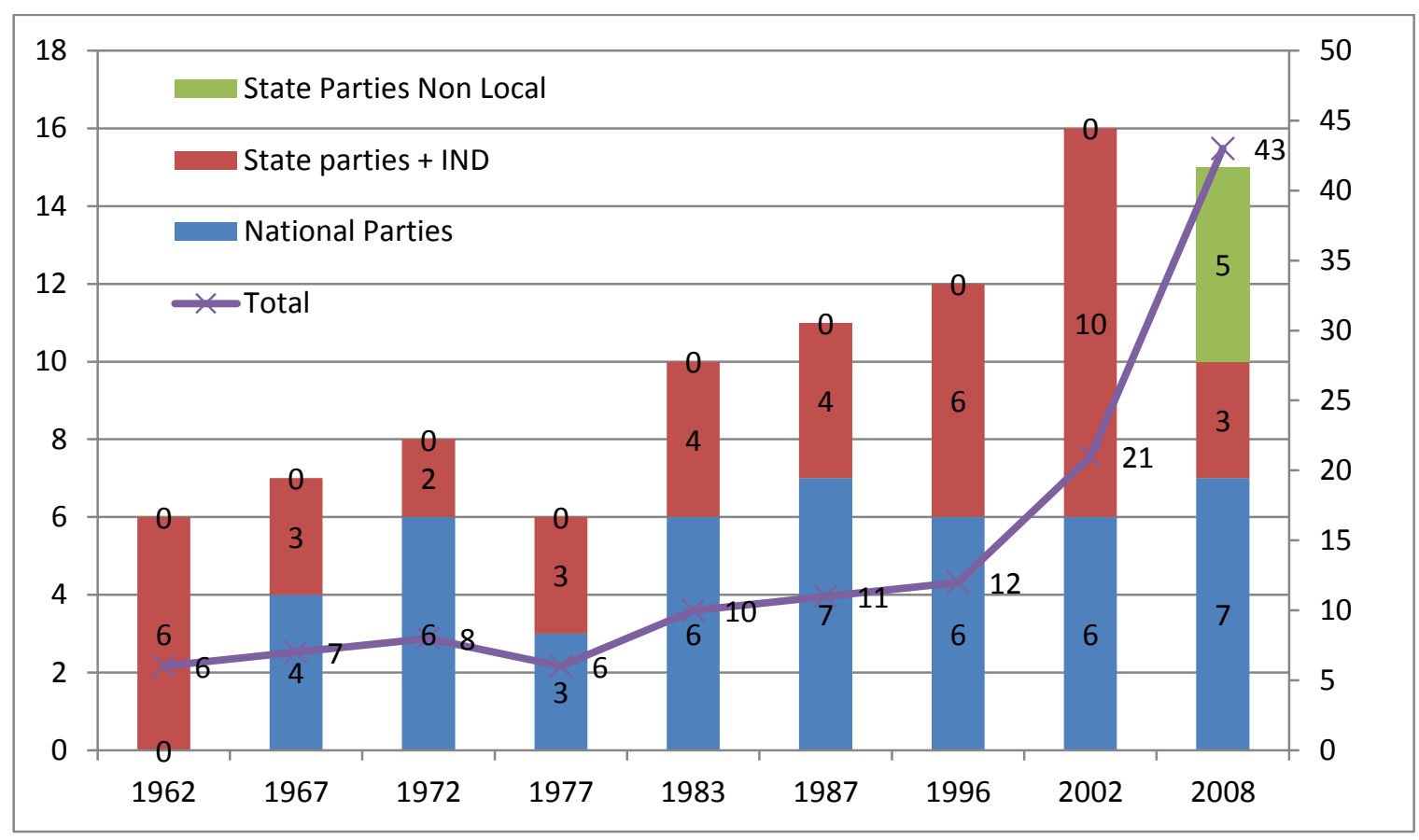

Figure 1.

The first leg lasted from 1962 to 1972 during which elections were contested on 75 seats each, the second leg lasted from 1977 to 1987 during which elections were contested on 76 seats each and in the third leg lasted from 1996 to 2008 during which elections were contested on 87 seats each. The nature of parties which participated during all the elections so far include national parties, state parties (local), state parties (non-local) and independent candidates. The average percentage of parties which contested elections in the state so far comprised of 36.29 $\%$ national parties, $33.06 \%$ local state parties and independents and $30.64 \%$ non-local state parties. During the election year 1962 only 6 political parties contested the elections and the number grew to 124 political parties during 2008 elections, which can also be termed as an increase of $1966.66 \%$ parties with an average growth of $30.16 \%$ during each election. On average 14 parties contested each assembly election. If we look at the corresponding growth of the political parties' negative growth was observed during the election year 1977 when $25 \%$ decline was observed from the previous election, while as during rest of the election there was increase in the parties contesting elections from each corresponding election year. Trend has also grown in the state where non-local state parties have also started participating in the electoral process of the state.

Above tabulation distribution reflects the success and share percentage of candidates fielded by national political parties, state political parties of both local and non-local nature and independent candidates during different assembly elections held in the state of Jammu \& Kashmir from 1962 to 2008 . The overall success percentage of candidates fielded by all the parties together during all the elections remained at $14.93 \%$, while as success percentage of candidates fielded by national parties remained at $21.52 \%$, state parties (local) had success percentage of $32.96 \%$, state parties (non-local) $0.32 \%$ and independents $2.46 \%$. On the overall seat share percentage front during all the elections, national parties bagged $38.65 \%$ seats, state parties local bagged $54.06 \%$ seats, state parties' non-local bagged $0.28 \%$ seats and independents had a share of $6.58 \%$ seats. 
Table II. Distribution of Candidates fielded by parties and their success $\&$ share percentage.

\begin{tabular}{|c|c|c|c|c|c|c|c|c|c|c|c|}
\hline $\begin{array}{c}\text { Nature of } \\
\text { Parties }\end{array}$ & Year $\rightarrow$ & 1962 & 1967 & 1972 & 1977 & 1983 & 1987 & 1996 & 2002 & 2008 & Total \\
\hline \multirow{4}{*}{$\begin{array}{c}\text { National } \\
\text { Parties }\end{array}$} & $\mathbf{C F}$ & - & 110 & 123 & 141 & 119 & 95 & 229 & 192 & 273 & 1282 \\
\hline & CE & - & 64 & 61 & 24 & 26 & 28 & 22 & 22 & 29 & 276 \\
\hline & SU\% & - & 58.18 & 49.59 & 17.02 & 21.84 & 29.47 & 9.60 & 11.45 & 10.10 & 21.52 \\
\hline & SH\% & - & 85.33 & 81.33 & 31.57 & 34.21 & 36.84 & 25.28 & 25.28 & 33.33 & 38.65 \\
\hline \multirow{4}{*}{$\begin{array}{l}\text { State Parties } \\
\quad \text { (Local) }\end{array}$} & CF & 136 & 58 & 22 & 94 & 139 & 89 & 184 & 213 & 236 & 1171 \\
\hline & $\mathrm{CE}$ & 73 & 8 & 5 & 48 & 47 & 40 & 63 & 50 & 52 & 386 \\
\hline & SU\% & 53.67 & 13.79 & 22.72 & 51.06 & 33.81 & 44.94 & 34.23 & 23.47 & 22.03 & 32.96 \\
\hline & SH\% & 97.33 & 10.66 & 6.66 & 63.15 & 61.84 & 52.63 & 72.41 & 57.47 & 59.77 & 54.06 \\
\hline \multirow{4}{*}{$\begin{array}{l}\text { State Parties } \\
\text { (Non-Local) }\end{array}$} & CF & - & - & - & - & - & - & - & 60 & 556 & 616 \\
\hline & CE & - & - & - & - & - & - & - & 0 & 2 & 2 \\
\hline & SU\% & - & - & - & - & - & - & - & 0 & 0.35 & 0.32 \\
\hline & SH\% & - & - & - & - & - & - & - & 0 & 2.29 & 0.28 \\
\hline \multirow{4}{*}{ Independents } & $\mathbf{C F}$ & 38 & 38 & 197 & 174 & 254 & 344 & 134 & 244 & 481 & 1904 \\
\hline & $\mathrm{CE}$ & 2 & 3 & 9 & 4 & 2 & 8 & 2 & 13 & 4 & 47 \\
\hline & SU\% & 5.26 & 7.89 & 4.56 & 2.29 & 0.78 & 2.32 & 1.49 & 5.32 & 0.83 & 2.46 \\
\hline & SH\% & 2.66 & 4.00 & 12.00 & 5.26 & 2.63 & 10.52 & 2.29 & 14.94 & 4.59 & 6.58 \\
\hline \multirow{3}{*}{ Total } & CF & 174 & 206 & 342 & 409 & 512 & 528 & 547 & 709 & 1354 & 4781 \\
\hline & $\mathrm{CE}$ & 75 & 75 & 75 & 76 & 76 & 76 & 87 & 87 & 87 & 714 \\
\hline & SU\% & 43.10 & 36.40 & 21.92 & 18.58 & 14.84 & 14.39 & 15.90 & 12.27 & 6.42 & 14.93 \\
\hline
\end{tabular}

CF-Candidates Fielded, CE-Candidates Elected, SU\%-Success Percentage, SH\%-Share Percentage

Table III. Candidates per Constituency.

\begin{tabular}{|c|c|c|c|c|c|c|}
\hline \multirow{2}{*}{ Year } & \multirow{2}{*}{$\begin{array}{l}\text { Total } \\
\text { Seats }\end{array}$} & \multicolumn{4}{|c|}{ Candidate Fielded } & \multirow{2}{*}{$\begin{array}{c}\text { Corresponding } \\
\text { Growth (\%) }\end{array}$} \\
\cline { 3 - 6 } & & Max & Total & $\begin{array}{c}\text { Average } \\
\text { Candidates }\end{array}$ & - \\
\hline 1962 & 75 & 1 & 7 & 174 & 2.32 & $32(18.39)$ \\
\hline 1967 & 75 & 1 & 8 & 206 & 2.74 & $136(79.12)$ \\
\hline 1972 & 75 & 1 & 16 & 342 & 4.56 & $67(19.59)$ \\
\hline 1977 & 76 & 2 & 14 & 409 & 5.38 & $103(25.18)$ \\
\hline 1983 & 76 & 1 & 19 & 512 & 6.73 & $16(3.12)$ \\
\hline 1987 & 76 & 2 & 24 & 528 & 6.94 & $19(3.59)$ \\
\hline 1996 & 87 & 2 & 14 & 547 & 6.28 & $162(29.61)$ \\
\hline 2002 & 87 & 1 & 22 & 709 & 8.14 & $645(90.97)$ \\
\hline 2008 & 87 & 4 & 34 & 1354 & 15.56 & $131.11(29.95)$ \\
\hline Avg & 714 & 1.66 & 17.55 & 4781 & 7.37 & \\
\hline
\end{tabular}




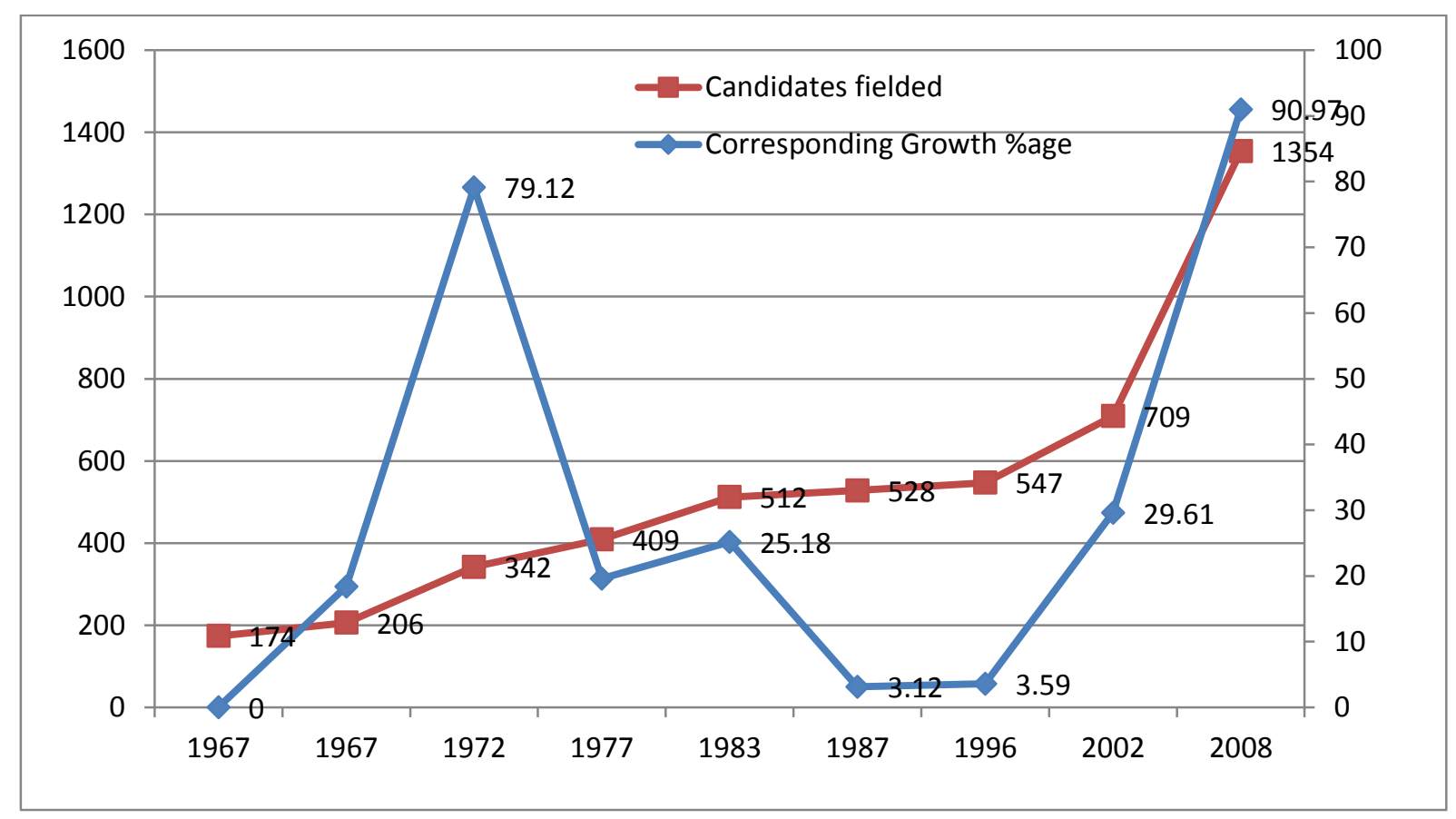

Figure 2.

As we move from election to election, constant growth is recorded in the candidates fielded during each election. If we look at the corresponding growth of the candidates fielded, positive growth was observed during each election with an average growth of $29.95 \%$. The average candidates fielded during each election ranged between minimum 1.66 candidates per seat to maximum 17.55 candidates. Average candidates contested against each seat remained 7.37, while as a maximum of 34 candidates contested against one seat during 2008 elections while as a minimum 1 candidate contested during 1962, 1967, 1972, 1983 \& 2002.

Table IV. Distribution of Candidates fielded \& Women Representation.

\begin{tabular}{|c|c|c|c|c|c|c|c|c|c|}
\hline \multirow{2}{*}{ Year } & \multirow{2}{*}{$\begin{array}{l}\text { Total } \\
\text { Seats }\end{array}$} & \multicolumn{3}{|c|}{ Candidate Fielded } & \multicolumn{3}{c|}{ Elected } & \multicolumn{2}{c|}{ Success \% age } \\
\cline { 3 - 9 } & & Male (\%) & $\begin{array}{c}\text { Female } \\
(\%)\end{array}$ & Total & Male (\%) & $\begin{array}{c}\text { Female } \\
(\%)\end{array}$ & Total & Male & Female \\
\hline 1962 & 75 & $173(99.42)$ & $1(0.58)$ & 174 & $75(100)$ & 0 & 75 & 43.35 & 0 \\
\hline 1967 & 75 & $205(99.51)$ & $1(0.49)$ & 206 & $75(100)$ & 0 & 75 & 36.58 & 0 \\
\hline 1972 & 75 & $334(97.66)$ & $8(2.34)$ & 342 & $71(94.67)$ & $4(5.33)$ & 75 & 21.25 & 50.00 \\
\hline 1977 & 76 & $405(99.02)$ & $4(0.98)$ & 409 & $75(98.69)$ & $1(1.31)$ & 76 & 18.51 & 25.00 \\
\hline 1983 & 76 & $505(98.63)$ & $7(1.37)$ & 512 & $76(100)$ & 0 & 76 & 15.04 & 0 \\
\hline 1987 & 76 & $515(97.53)$ & $13(2.47)$ & 528 & $75(98.69)$ & $1(1.31)$ & 76 & 14.56 & 7.69 \\
\hline 1996 & 87 & $532(97.25)$ & $15(274)$ & 547 & $85(97.71)$ & $2(2.29)$ & 87 & 15.97 & 13.33 \\
\hline 2002 & 87 & $679(95.76)$ & $30(4.24)$ & 709 & $85(97.71)$ & $2(2.29)$ & 87 & 12.51 & 6.66 \\
\hline 2008 & 87 & $1287(95.05)$ & $67(4.95)$ & 1354 & $84(96.56)$ & $3(3.44)$ & 87 & 6.52 & 4.47 \\
\hline Avg & & $4635(96.94)$ & $146(3.05)$ & 4781 & $701(98.17)$ & $13(1.82)$ & 714 & 20.47 & 11.90 \\
\hline
\end{tabular}




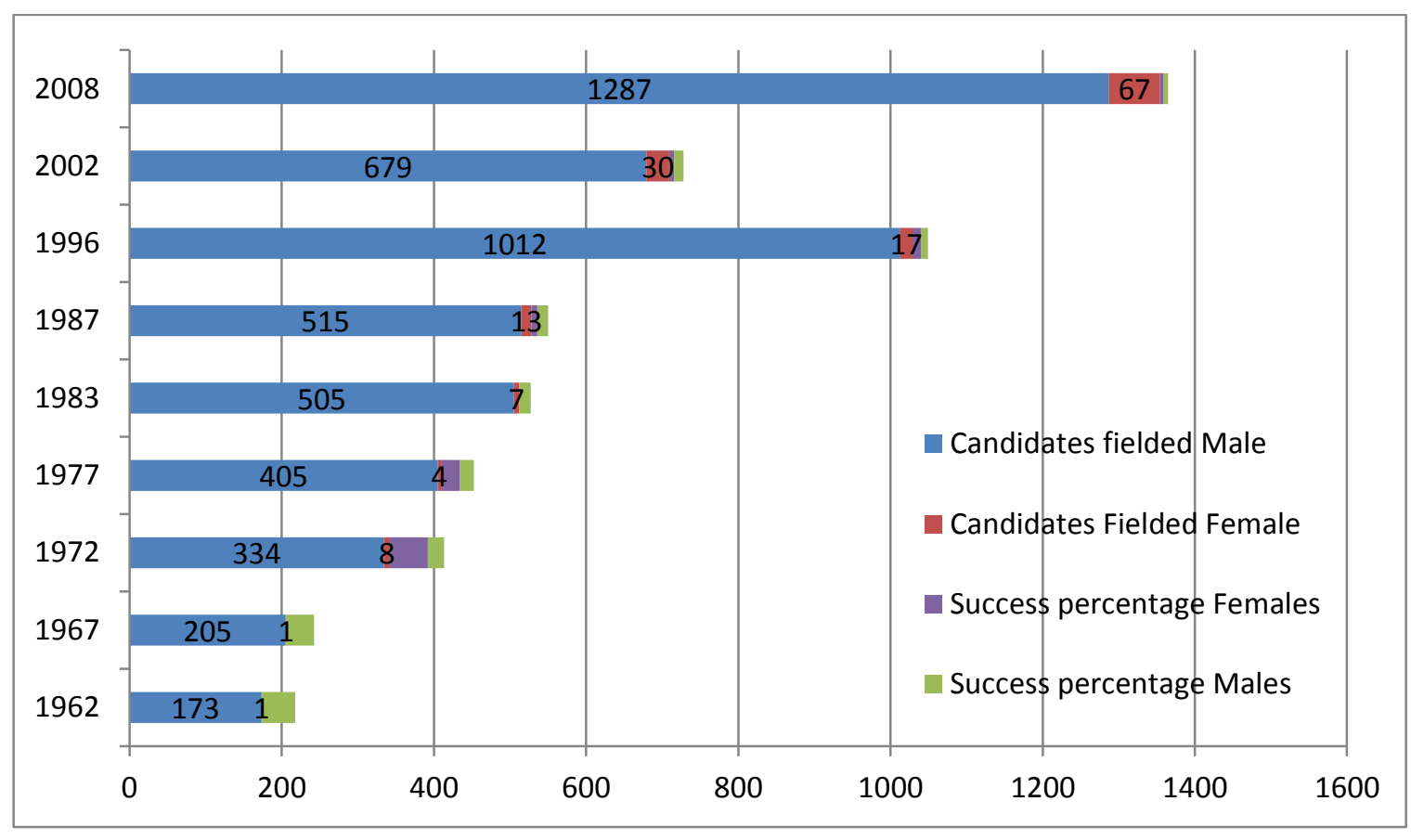

Figure 3.

Compared to male contestants female contestants have been given far less representation in each assembly election, even the representation given to women contestants during 1962, 1967 and 1977 assembly elections was less than $1 \%$, while as the maximum $4.95 \%$ representation was given to women candidates during the election year 2008. Scenario of candidates elected to each assembly is almost same to that of candidates fielded. During 1962, 1967 and 1983 there was $100 \%$ male representation in legislative assembly, while as a maximum of 4 women candidates were elected to assembly during the 1972 elections which is the highest number in the entire history of democratic process of Jammu \& Kashmir.

Table VI. Reservation of Number and Type of Constituencies.

\begin{tabular}{|c|c|c|c|c|}
\hline Year & Gen & SC & ST & Total \\
\hline 1962 & $71(94.66)$ & $4(5.33)$ & - & 75 \\
\hline 1967 & $69(92.00)$ & $6(8.00)$ & - & 75 \\
\hline 1972 & $69(92.00)$ & $6(8.00)$ & - & 75 \\
\hline 1977 & $70(92.10)$ & $6(7.89)$ & - & 76 \\
\hline 1983 & $70(92.10)$ & $6(7.89)$ & - & 76 \\
\hline 1987 & $66(86.84)$ & $10(13.15)$ & - & 76 \\
\hline 1996 & $80(91.95)$ & $7(8.04)$ & - & 87 \\
\hline 2002 & $80(91.95)$ & $7(8.04)$ & - & 87 \\
\hline 2008 & $80(91.95)$ & $7(8.04)$ & - & 87 \\
\hline Avg & $655(91.73)$ & $59(8.26)$ & - & 714 \\
\hline
\end{tabular}

Gen-General Candidates, SC-Scheduled Caste, ST-Scheduled Tribe 
During the 1962 election only 173 candidates contested on 75 seats and the number kept on increasing during the subsequent elections, in 2008 against 87 seats 1287 candidates were in fray. Given this fact with the increase in the number of contestants fielded during each election, the success percentage is bound to decline. On average $96.94 \%$ contestants fielded during all the assembly elections were male candidates and meager $3.05 \%$ females. The proportionality of fielding candidates gets equally reflected in terms of candidates elected as compared to $98.17 \%$ male candidates' only $1.82 \%$ female candidates were elected on average to each assembly with success percentage of $20.47 \%$ and $11.90 \%$ respectively.

Constitution of India has laid provisions for representation of downtrodden sections of Indian society in parliament by reserving seats for such sections of society. To carry on with welfare measures of such societies, govt of Jammu \& Kashmir has extended this reservation to $\mathrm{SC}$ and ST communities of the state by reserving some seats. Although there is proviso for reservation of assembly seats for ST community but far past 9 assembly elections no seat was reserved for the community even in those areas where the community is concentrated. On average during all the assembly election held in the state $91.73 \%$ seats were reserved for general candidates and $8.26 \%$ for SC candidates

Table VIII. Year wise status of electors in Jammu \& Kashmir.

\begin{tabular}{|c|c|c|c|c|c|c|c|c|c|c|c|}
\hline \multirow{2}{*}{ Year } & \multirow{2}{*}{$\begin{array}{l}\text { No of } \\
\text { Seats }\end{array}$} & \multicolumn{4}{|c|}{$\begin{array}{c}\text { Total } \\
\text { Electorate }\end{array}$} & \multicolumn{3}{|c|}{ Turnout } & \multicolumn{2}{|c|}{$\begin{array}{c}\text { \%age } \\
\text { Turnout }\end{array}$} & \multirow{2}{*}{$\begin{array}{c}\begin{array}{c}\text { Total } \\
\text { Turnout }\end{array} \\
\text { \%age }\end{array}$} \\
\hline & & Male & Female & Total & CG\% & Male (\%) & $\begin{array}{c}\text { Female } \\
(\%)\end{array}$ & Total (\%) & Male & Female & \\
\hline 1962 & 75 & 1843930 & NA & 1843930 & - & 743806 & NA & 743806 & 40.34 & NA & 40.34 \\
\hline 1967 & 75 & 784072 & 635181 & 1419253 & -23.03 & 497363 & 337052 & 834415 & 63.43 & 53.06 & 58.79 \\
\hline 1972 & 75 & 1235552 & 1062399 & 2297951 & 61.91 & 855809 & 572886 & 1428695 & 69.27 & 53.92 & 62.17 \\
\hline 1977 & 76 & 1431690 & 1253302 & 2684992 & 16.84 & 1047206 & 756898 & 1804104 & 73.14 & 60.39 & 67.19 \\
\hline 1983 & 76 & 1688648 & 1413017 & 3101665 & 15.51 & 1275985 & 995824 & 2271809 & 75.56 & 70.48 & 73.24 \\
\hline 1987 & 76 & 1937104 & 1618445 & 3555549 & 14.63 & 1523611 & 1138744 & 2662355 & 78.65 & 70.36 & 74.88 \\
\hline 1996 & 87 & 2575213 & 2185882 & 4761095 & 33.90 & 1559789 & 1007249 & 2567038 & 60.57 & 46.50 & 53.92 \\
\hline 2002 & 87 & 3308163 & 2770407 & 6078570 & 27.67 & 1596484 & 1060143 & 2656627 & 48.26 & 38.27 & 43.70 \\
\hline 2008 & 87 & 3364265 & 3097492 & 6461757 & 6.30 & 2128882 & 1823212 & 3952094 & 63.28 & 58.86 & 61.16 \\
\hline $\begin{array}{c}\text { Total } \\
\& \\
\text { (Avg) }\end{array}$ & $\begin{array}{c}714 \\
(79.33)\end{array}$ & $\begin{array}{l}18168637 \\
(201873)\end{array}$ & $\begin{array}{c}14036125 \\
(175451)\end{array}$ & $\begin{array}{l}32204762 \\
(3578306)\end{array}$ & $\begin{array}{l}153.73 \\
(17.08)\end{array}$ & $\begin{array}{l}11228935 \\
(1247659)\end{array}$ & $\begin{array}{r}7692008 \\
(961501)\end{array}$ & $\begin{array}{l}18920943 \\
(2102327)\end{array}$ & $\begin{array}{c}572.5 \\
(63.61 \\
)\end{array}$ & $\begin{array}{l}451.84 \\
(55.48)\end{array}$ & $\begin{array}{l}535.39 \\
(59.48)\end{array}$ \\
\hline
\end{tabular}

NA-Not Available, CG \% - Corresponding Growth Percentage

Public participation in elections is the actual manifestation of democratic exercise, more the participation of public in electoral process more is held the exercise healthy and true to its purpose. The participation of state electorate in the democratic exercise during successive elections reflects their faith in country's democratic process and is in itself is contradiction to those voices who rate Jammu \& Kashmir as conflict zone and question the accession of state to the union of India.

During the entire electoral history of Jammu \& Kashmir, Male electoral has outnumbered the female electoral with an average male voter turnout of $63.61 \%$ to that of $55.48 \%$ female voter turnout. 


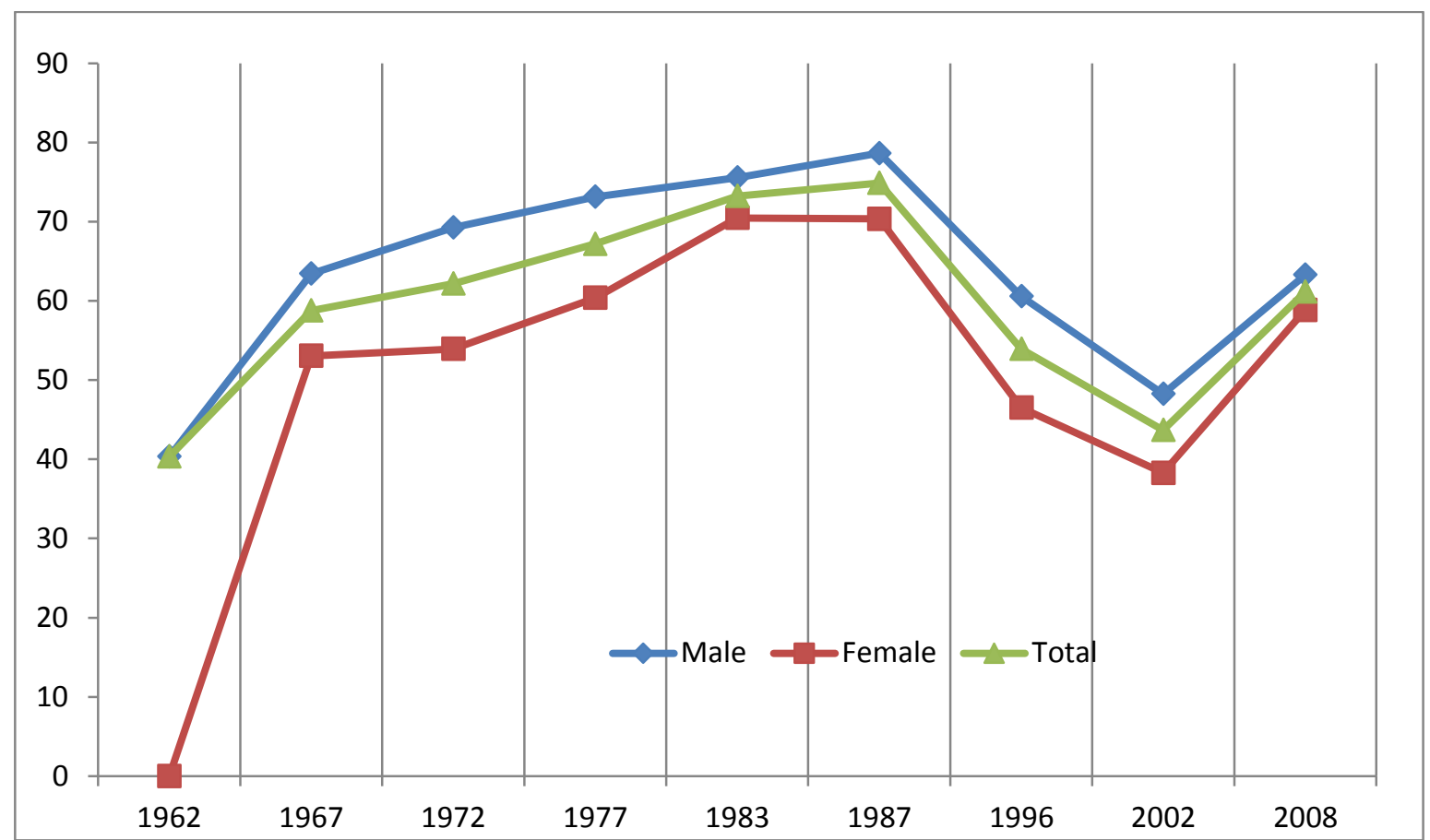

Figure 4.

Gross voter turnout during all the assembly elections of the state remained at $59.48 \%$. The figures reflected are even better than the national voter turnout of general elections, where overall average male voter turnout so far remained at $57.77 \%$ and female voter turnout 42.23 $\%$, while as the average gross voter turnout so far remained $59.17 \%$. The electorate of Jammu $\&$ Kashmir on average grew at $17.08 \%$ during each election.

Table IX. Distribution of vote share among National \& State Level Political Parties Including Independents.

\begin{tabular}{|c|c|c|c|c|c|c|c|c|c|c|}
\hline \multirow{2}{*}{ Year } & \multirow{2}{*}{$\begin{array}{l}\text { No of } \\
\text { Seats }\end{array}$} & \multicolumn{5}{|c|}{ Total valid votes obtained } & \multicolumn{4}{|c|}{ \%age Share } \\
\hline & & NP & SPL & SPN & IND & TVV & NP & SPL & SPN & IND \\
\hline 1962 & 75 & - & 671974 & - & 53892 & 725866 & - & 92.57 & - & 7.43 \\
\hline 1967 & 75 & 567626 & 163569 & - & 68377 & 799572 & 70.99 & 20.45 & - & 8.55 \\
\hline 1972 & 75 & 910959 & 98985 & - & 369062 & 1379006 & 66.05 & 7.17 & - & 26.76 \\
\hline 1977 & 76 & 711073 & 869820 & - & 165477 & 1746370 & 40.71 & 49.80 & - & 9.47 \\
\hline 1983 & 76 & 751340 & 1224873 & - & 220904 & 2197117 & 34.19 & 55.74 & - & 10.05 \\
\hline 1987 & 76 & 695497 & 1001297 & - & 903971 & 2600765 & 26.74 & 38.50 & - & 34.75 \\
\hline 1996 & 87 & 1110488 & 1141323 & - & 231111 & 2482922 & 44.72 & 45.96 & - & 9.30 \\
\hline 2002 & 87 & 1789078 & 397279 & 30926 & 438287 & 2655570 & 67.37 & 14.96 & 1.16 & 16.50 \\
\hline 2008 & 87 & 1391852 & 1657137 & 268767 & 647888 & 3965644 & 35.09 & 41.78 & 6.77 & 16.33 \\
\hline $\begin{array}{c}\text { Total \& } \\
\text { (Avg) }\end{array}$ & $\begin{array}{c}714 \\
(79.33)\end{array}$ & $\begin{array}{l}7927913 \\
(990989)\end{array}$ & $\begin{array}{c}7226257 \\
(80291)\end{array}$ & $\begin{array}{c}299693 \\
(149846)\end{array}$ & $\begin{array}{l}3098969 \\
(344329)\end{array}$ & $\begin{array}{l}18552832 \\
(2061425)\end{array}$ & $\begin{array}{l}385.86 \\
(48.23)\end{array}$ & $\begin{array}{l}366.93 \\
(40.77)\end{array}$ & $\begin{array}{c}7.93 \\
(3.96)\end{array}$ & $\begin{array}{l}139.14 \\
(15.46)\end{array}$ \\
\hline
\end{tabular}

NP-National Parties, SPL-State Parties Local, SPN-State Parties Non-Local, IND-Independents, TVV-Total Valid Votes 


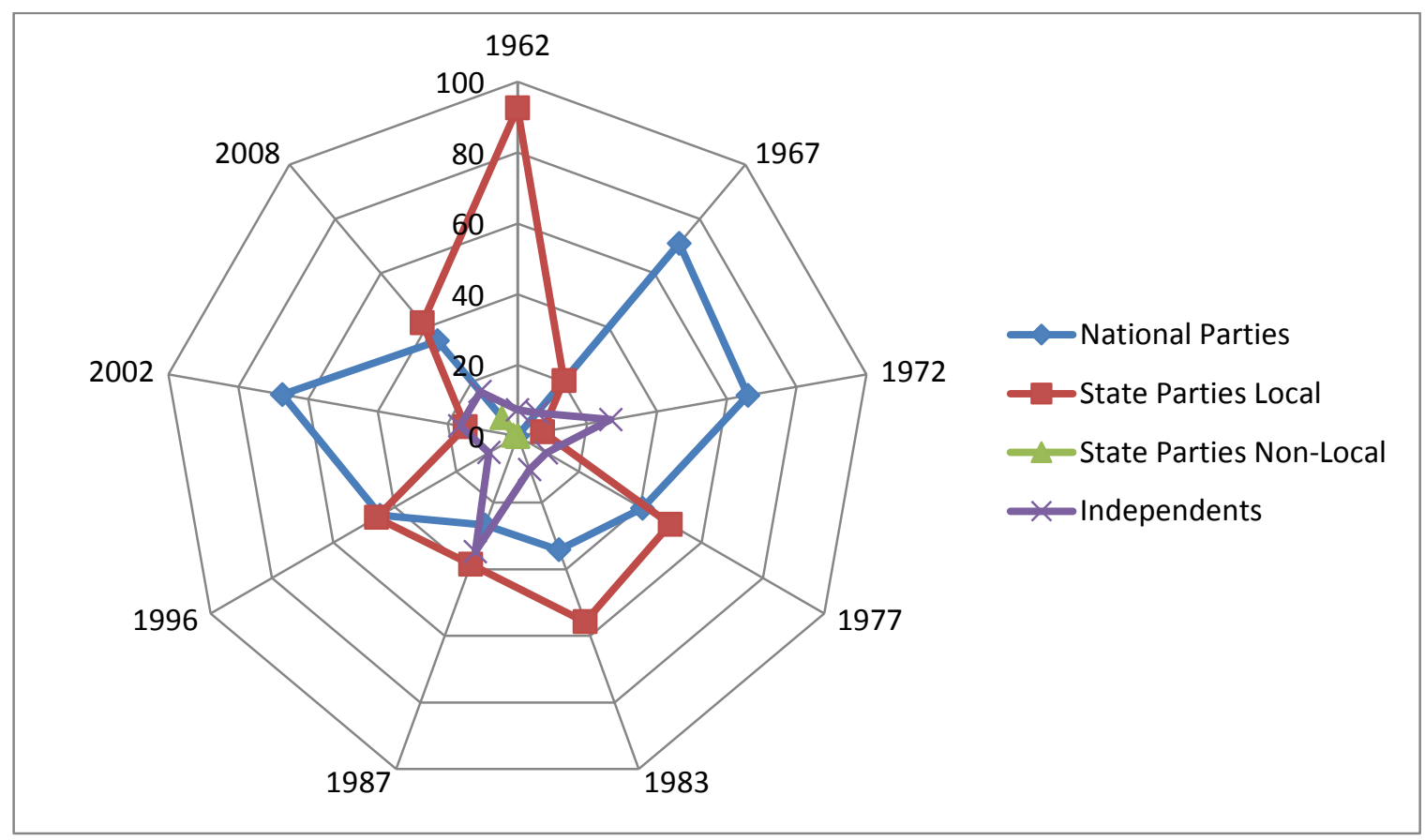

Figure 5.

Presence of political parties in a region or state not gets only reflected by the number of seats a party wins during a particular election but also by the number of votes secured by a party during that very election or by looking at the votes secured by parties during subsequent elections. Fact also remains that in multiparty system wining seats is about emerging single largest party with highest voter turn our among all the contesting parties while as securing percentage of votes reflects the true representation of electoral and these are altogether two different things. This gets reflected by the fact that Jammu \& Kashmir state during most part remained ruled by state level political parties but in terms of vote share percentage, on average national parties have secured $48.23 \%$ votes during each election, state parties local $40.77 \%$ state parties non-local $3.93 \%$ and Independents $15.46 \%$

Table X. Candidates Forfeited Deposits.

\begin{tabular}{|c|c|c|c|c|c|c|c|c|c|}
\hline \multirow{2}{*}{ Year } & \multicolumn{3}{|c|}{ Contestants } & \multicolumn{3}{c|}{ Elected } & \multicolumn{3}{c|}{ Forfeited Deposits } \\
\cline { 2 - 10 } & Male & Female & Total & Male & Female & Total & Male (\%) & Female (\%) & Total (\%) \\
\hline 1962 & 173 & 1 & 174 & 75 & 0 & 75 & $68(39.30)$ & $0(0)$ & $68(39.08)$ \\
\hline 1967 & 205 & 1 & 206 & 75 & 0 & 75 & $73(35.60)$ & $1(100.00)$ & $74(35.92)$ \\
\hline 1972 & 334 & 8 & 342 & 71 & 4 & 75 & $196(58.68)$ & $4(50.00)$ & $200(58.47)$ \\
\hline 1977 & 405 & 4 & 409 & 75 & 1 & 76 & $254(62.71)$ & $2(50.00)$ & $256(62.59)$ \\
\hline 1983 & 505 & 7 & 512 & 76 & 0 & 76 & $351(69.50)$ & $6(85.71)$ & $357(69.72)$ \\
\hline 1987 & 528 & 13 & 528 & 75 & 1 & 76 & $361(68.37)$ & $11(84.61)$ & $372(70.45)$ \\
\hline 1996 & 532 & 15 & 547 & 83 & 2 & 87 & $347(65.22)$ & $10(66.66)$ & $357(65.26)$ \\
\hline 2002 & 679 & 30 & 709 & 85 & 2 & 87 & $485(71.42)$ & $26(86.66)$ & $511(72.07)$ \\
\hline 2008 & 1287 & 67 & 1354 & 84 & 3 & 87 & $1105(85.85)$ & $56(83.58)$ & $1161(85.74)$ \\
\hline Total & 4648 & 146 & 4762 & 699 & 13 & 714 & $3240(69.70)$ & $116(79.45)$ & $3356(70.47)$ \\
\hline
\end{tabular}


Forfeiture of deposits in elections is the age old practice, which is also seen as humiliating defeat for a candidate. In the above tabulation attempt has been made to reflect the forfeiture percentage of candidates with overview on gender based forfeiture percentage. On average $70.47 \%$ candidates forfeit their deposits in assembly elections of Jammu \& Kashmir which on average constitute $69.70 \%$ male contestants and $79.45 \%$ female contestants.

Table XI. Distribution \& Growth of Polling Station with Average Electors.

\begin{tabular}{|c|c|c|c|c|c|c|}
\hline Year & $\begin{array}{c}\text { No of } \\
\text { Constit- } \\
\text { uencies }\end{array}$ & $\begin{array}{c}\text { No of } \\
\text { polling } \\
\text { Stations }\end{array}$ & $\begin{array}{c}\text { Corresp- } \\
\text { onding } \\
\text { Growth }\end{array}$ & $\begin{array}{c}\text { Corresp- } \\
\text { onding } \\
\text { \%age } \\
\text { Growth }\end{array}$ & $\begin{array}{c}\text { Average } \\
\text { Polling } \\
\text { Stations }\end{array}$ & $\begin{array}{c}\text { Average } \\
\text { Electors } \\
\text { per Polling } \\
\text { Station }\end{array}$ \\
\hline 1962 & 75 & 75 & - & - & 1.00 & 24586 \\
\hline 1967 & 75 & 2525 & 2450 & 3266.66 & 33.66 & 562 \\
\hline 1972 & 75 & 3859 & 1334 & 52.83 & 51.45 & 595 \\
\hline 1977 & 76 & 4236 & 377 & 9.76 & 55.73 & 634 \\
\hline 1983 & 76 & 4992 & 756 & 17.84 & 65.73 & 621 \\
\hline 1987 & 76 & 5645 & 653 & 13.08 & 74.27 & 630 \\
\hline 1996 & 87 & 6324 & 679 & 12.02 & 72.68 & 753 \\
\hline 2002 & 87 & 7083 & 759 & 12.00 & 81.41 & 870 \\
\hline 2008 & 87 & 9077 & 1994 & 25.15 & 104.33 & 712 \\
\hline $\begin{array}{c}\text { Total \& } \\
(\text { Avg })\end{array}$ & 714 & 43816 & 9002 & 3409.34 & 540.26 & 29963 \\
$(79.33)$ & $(4868.44)$ & $(1000.22)$ & $(378.81)$ & $(60.02)$ & $(499)$ \\
\hline
\end{tabular}

Greater public participation in the electoral process of the country can be ensured by having sufficient arrangements in place so as to help easy and smooth conduct of elections. One important and indispensible aspect in this direction is the number of polling stations established to do the needful. From each assembly election the polling stations in Jammu \& Kashmir grew at $378.81 \%$ with an average 499 electors to each polling station.

Table XII. Performance of some leading political parties in terms of candidates fielded and Elected.

\begin{tabular}{|c|c|c|c|c|c|c|c|c|c|c|c|c|}
\hline \multicolumn{3}{|c|}{ Party Name } & \multirow{2}{*}{$\begin{array}{c}1962 \\
75\end{array}$} & \multirow{2}{*}{$\begin{array}{c}1967 \\
38\end{array}$} & \multirow{2}{*}{1972} & \multirow{2}{*}{$\begin{array}{c}1977 \\
75\end{array}$} & \multirow{2}{*}{$\begin{array}{c}1983 \\
75\end{array}$} & \multirow{2}{*}{$\begin{array}{r}1987 \\
45\end{array}$} & \multirow{2}{*}{$\begin{array}{c}1996 \\
81\end{array}$} & \multirow{2}{*}{$\begin{array}{r}2002 \\
85\end{array}$} & \multirow{2}{*}{$\begin{array}{c}2008 \\
85\end{array}$} & \multirow{2}{*}{$\begin{array}{l}\text { Avg. } \\
69.87\end{array}$} \\
\hline National & JWY & CF & & & & & & & & & & \\
\hline conference & JKN & $\overline{C E}$ & 70 & 8 & & 47 & 46 & 40 & 57 & 28 & 28 & 40.50 \\
\hline \multirow{2}{*}{$\begin{array}{c}\text { Communist Party } \\
\text { of India }\end{array}$} & \multirow{2}{*}{ CPI } & CF & & 3 & 1 & 6 & 3 & 7 & 3 & 5 & 7 & 4.37 \\
\hline & & $\mathrm{CE}$ & & 0 & 0 & 0 & 0 & 0 & 0 & 0 & 0 & 0 \\
\hline \multirow{2}{*}{$\begin{array}{l}\text { Indian National } \\
\text { congress }\end{array}$} & \multirow{2}{*}{ INC } & CF & & 75 & 74 & 63 & 71 & 31 & 84 & 78 & 78 & 69.25 \\
\hline & & $\mathrm{CE}$ & & 61 & 58 & 11 & 26 & 26 & 7 & 20 & 17 & 28.25 \\
\hline \multirow{2}{*}{$\begin{array}{l}\text { Communist party } \\
\text { of India (M) }\end{array}$} & \multirow{2}{*}{ CPM } & CF & & & & & 1 & 3 & 4 & 7 & 8 & 4.6 \\
\hline & & CE & & & & & 0 & 0 & 1 & 2 & 1 & 0.80 \\
\hline
\end{tabular}




\begin{tabular}{|c|c|c|c|c|c|c|c|c|c|c|c|c|}
\hline \multirow{2}{*}{$\begin{array}{c}\text { Bhartiya Janta } \\
\text { Party }\end{array}$} & \multirow{2}{*}{ BJP } & CF & & & & & 27 & 29 & 53 & 58 & 64 & 46.20 \\
\hline & & $\mathrm{CE}$ & & & & & 0 & 2 & 8 & 1 & 11 & 4.40 \\
\hline \multirow{2}{*}{$\begin{array}{l}\text { Jammu Kashmir } \\
\text { Panthers Party }\end{array}$} & \multirow{2}{*}{ JPP } & CF & & & & & & 21 & 45 & 36 & 73 & 43.75 \\
\hline & & $\mathbf{C E}$ & & & & & & 0 & 1 & 4 & 3 & 2 \\
\hline \multirow{2}{*}{$\begin{array}{l}\text { Bhujan Samaj } \\
\text { Party }\end{array}$} & \multirow{2}{*}{ BSP } & $\mathbf{C F}$ & & & & & & & 29 & 33 & 83 & 48.33 \\
\hline & & $\mathbf{C E}$ & & & & & & & 4 & 1 & 0 & 1.66 \\
\hline \multirow{2}{*}{ Janta Dal } & \multirow{2}{*}{ JDU } & $\mathbf{C F}$ & & & & & & & 76 & 19 & 7 & 34 \\
\hline & & $\mathbf{C E}$ & & & & & & & 5 & 0 & 0 & 1.66 \\
\hline \multirow{2}{*}{$\begin{array}{c}\text { Peoples } \\
\text { Democratic Party }\end{array}$} & \multirow{2}{*}{ PDP } & CF & & & & & & & & 59 & 78 & 68.50 \\
\hline & & $\mathrm{CE}$ & & & & & & & & 16 & 21 & 18.50 \\
\hline \multirow{2}{*}{ Independents } & \multirow{2}{*}{ IND } & CF & 38 & 38 & 197 & 174 & 254 & 344 & 134 & 244 & 481 & 211.55 \\
\hline & & $\mathbf{C E}$ & 2 & 3 & 9 & 4 & 2 & 8 & 2 & 13 & 4 & 5.22 \\
\hline \multirow{2}{*}{ Others } & \multirow{2}{*}{ OTH } & $\mathbf{C F}$ & 61 & 52 & 70 & 91 & 81 & 48 & 38 & 85 & 390 & 101.77 \\
\hline & & $\mathbf{C E}$ & 3 & 3 & 8 & 14 & 1 & 0 & 2 & 2 & 2 & 3.88 \\
\hline \multirow{2}{*}{ Total } & \multirow{2}{*}{ TOT } & CF & 174 & 206 & 342 & 409 & 512 & 528 & 547 & 709 & 1354 & 531.22 \\
\hline & & $\mathbf{C E}$ & 75 & 75 & 75 & 76 & 76 & 76 & 87 & 87 & 87 & 79.33 \\
\hline
\end{tabular}

CF-Candidate Fielded, CE-Candidates Elected

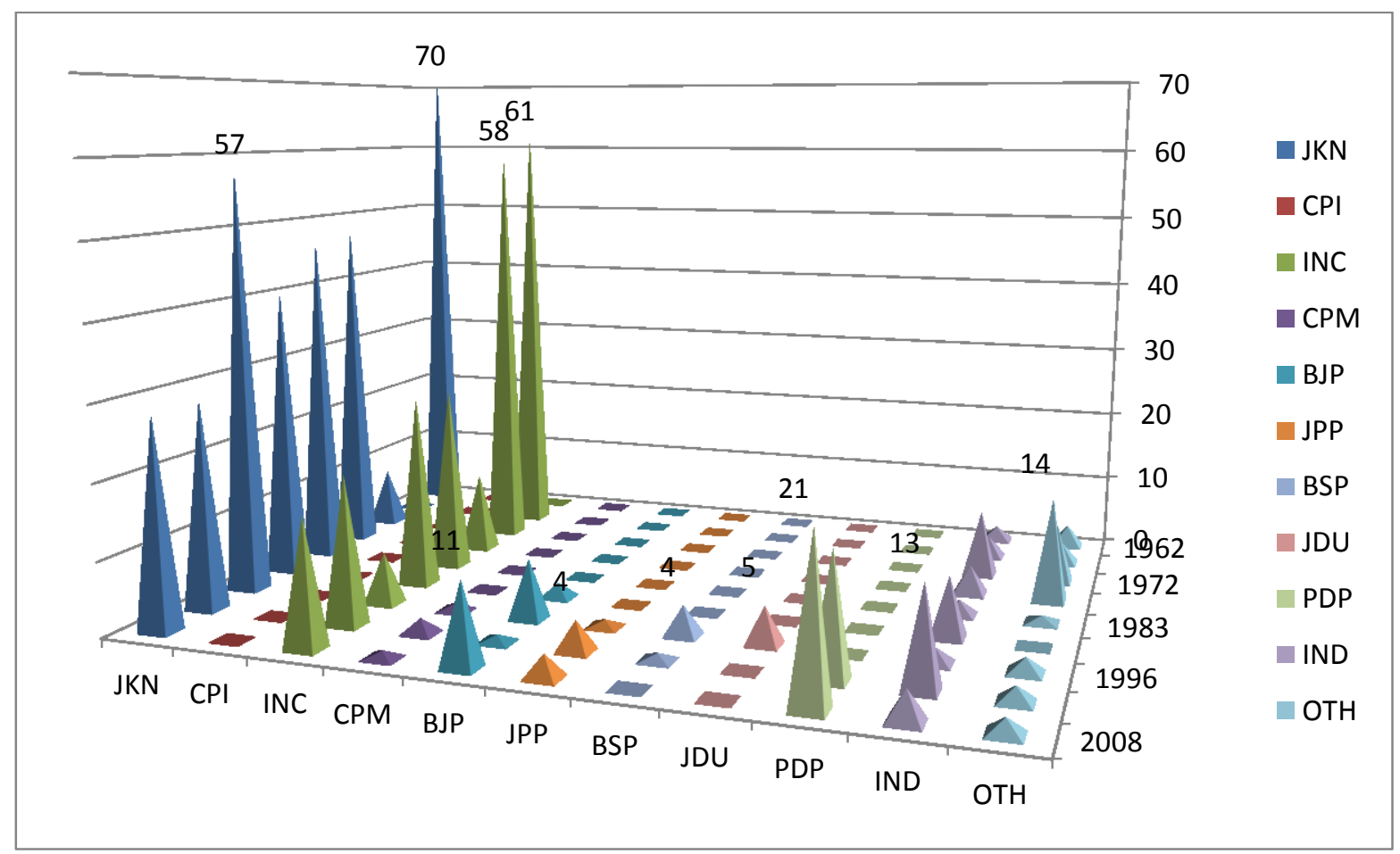

Figure 6.

Political parties under study in the above tabulation are some prominent ones of both national and state level enjoying fair amount of popularity among masses. National conference 
is one of the reckoned political forces of state and this gets better corroborated by the fact that on average the party fielded 69.87 candidates during each election with average success percentage of $40.50 \%$. Accordingly Indian national congress on average fielded 69.25 candidates with success rate of $28.25 \%$, CPI (M) fielded average 4.6 candidates with $0.80 \%$ success, BJP fielded average 46.20 candidates with $4.40 \%$ success. The average success percentage of candidates of JPP remained $2.00 \%$, BSP $1.66 \%$, JDU $1.66 \%$, PDP $18.50 \%$, Independents $5.22 \%$ and other $3.88 \%$. Peoples Democratic Party is one of the potential political parties from Kashmir region with fair amount of public following, which as a result helped party to come to power during its debut elections and do made some steady seat gain during the subsequent election. One noteworthy observation in the above tabulation is about the communist party of India which despite contesting 8 out of 9 assembly elections has not won even a single seat so far, while as CPI Marxist, the party with almost similar ideology has won seats in 4 out of five 5 elections contested.

Table XIII. Party Wise votes Obtained.

\begin{tabular}{|c|c|c|c|c|c|c|c|c|c|c|c|c|}
\hline \multicolumn{3}{|c|}{ Party Name } & 1962 & 1967 & 1972 & 1977 & 1983 & 1987 & 1996 & 2002 & 2008 & $\begin{array}{c}\text { Avg \% } \\
\text { age }\end{array}$ \\
\hline \multirow{2}{*}{$\begin{array}{l}\text { National } \\
\text { conference }\end{array}$} & \multirow{2}{*}{ JKN } & vo & 486060 & 137179 & & 807166 & 1039064 & 857830 & 863612 & 749825 & 914691 & 73192 \\
\hline & & $\% \mathrm{~S}$ & 66.96 & 17.16 & & 46.22 & 47.29 & 32.98 & 34.75 & 28.24 & 23.07 & 37.08 \\
\hline \multirow{2}{*}{$\begin{array}{l}\text { Communist } \\
\text { Party of India }\end{array}$} & \multirow{2}{*}{ CPI } & vo & & 4315 & 5160 & 1903 & 3435 & 5590 & 1391 & 4173 & 5619 & 3148 \\
\hline & & $\% \mathrm{~S}$ & & 0.54 & 0.37 & 0.11 & 0.16 & 0.21 & 0.06 & 0.16 & 0.14 & 0.21 \\
\hline \multirow{2}{*}{$\begin{array}{l}\text { Indian National } \\
\text { congress }\end{array}$} & \multirow{2}{*}{ INC } & vo & & 423922 & 764492 & 294911 & 666112 & 525261 & 496628 & 643751 & 702448 & 564690 \\
\hline & & $\% \mathrm{~S}$ & & 53.02 & 55.44 & 16.89 & 30.32 & 20.20 & 20.00 & 24.24 & 17.71 & 29.72 \\
\hline \multirow{2}{*}{$\begin{array}{l}\text { Communist } \\
\text { party of India } \\
\text { (M) }\end{array}$} & \multirow{2}{*}{ CPM } & Vo & & & & & 2168 & 5261 & 23774 & 23493 & 31614 & 17262 \\
\hline & & $\% \mathrm{~S}$ & & & & & 0.10 & 0.20 & 0.96 & 0.88 & 0.80 & 0.58 \\
\hline \multirow{2}{*}{$\begin{array}{c}\text { Bhartiya Janta } \\
\text { Party }\end{array}$} & \multirow{2}{*}{ BJP } & vo & & & & & 70193 & 132528 & 301238 & 227633 & 493757 & 24506 \\
\hline & & $\% \mathrm{~S}$ & & & & & 3.19 & 5.10 & 12.13 & 8.57 & 12.45 & 8.28 \\
\hline \multirow{2}{*}{$\begin{array}{c}\text { J \& K Panthers } \\
\text { Party }\end{array}$} & \multirow{2}{*}{ JPP } & vo & & & & & & 46043 & 55885 & 101830 & 131944 & 83928 \\
\hline & & $\% \mathrm{~S}$ & & & & & & 1.77 & 2.25 & 3.83 & 3.33 & 2.79 \\
\hline \multirow{2}{*}{$\begin{array}{l}\text { Bhujan Samaj } \\
\text { Party }\end{array}$} & \multirow{2}{*}{ BSP } & vo & & & & & & & 159690 & 119492 & 145644 & 141608 \\
\hline & & $\% \mathrm{~S}$ & & & & & & & 6.43 & 4.50 & 3.67 & 4.86 \\
\hline \multirow{2}{*}{ Janta Dal } & \multirow{2}{*}{ JDU } & vo & & & & & & & 269984 & 8083 & 1955 & 93340 \\
\hline & & $\% \mathrm{~S}$ & & & & & & & 10.87 & 0.30 & 0.05 & 3.74 \\
\hline \multirow{2}{*}{$\begin{array}{l}\text { Peoples } \\
\text { Democratic } \\
\text { Party }\end{array}$} & \multirow{2}{*}{ PDP } & vo & & & & & & & & 246480 & 610502 & 428491 \\
\hline & & $\% \mathrm{~S}$ & & & & & & & & 9.28 & 15.39 & 12.33 \\
\hline \multirow{2}{*}{ Independents } & \multirow{2}{*}{ IND } & vo & 53892 & 68377 & 369062 & 165477 & 220904 & 903971 & 231111 & 438287 & 647888 & 344329 \\
\hline & & $\% \mathrm{~S}$ & 7.42 & 8.55 & 26.76 & 9.48 & 10.05 & 34.76 & 9.31 & 16.50 & 16.34 & 15.46 \\
\hline \multirow{2}{*}{ Others } & \multirow{2}{*}{ OTH } & Vo & 185914 & 165779 & 240292 & 476913 & 195241 & 124281 & 79609 & 92523 & 279582 & 204459 \\
\hline & & $\% \mathrm{~S}$ & 25.6 & 20.69 & 17.43 & 17.31 & 8.89 & 4.79 & 3.2 & 3.49 & 6.22 & 11.95 \\
\hline Total & TOT & & 725866 & 799572 & 1379006 & 1746370 & 2197117 & 2600765 & 2482922 & 2655570 & 3965644 & 2061425 \\
\hline
\end{tabular}




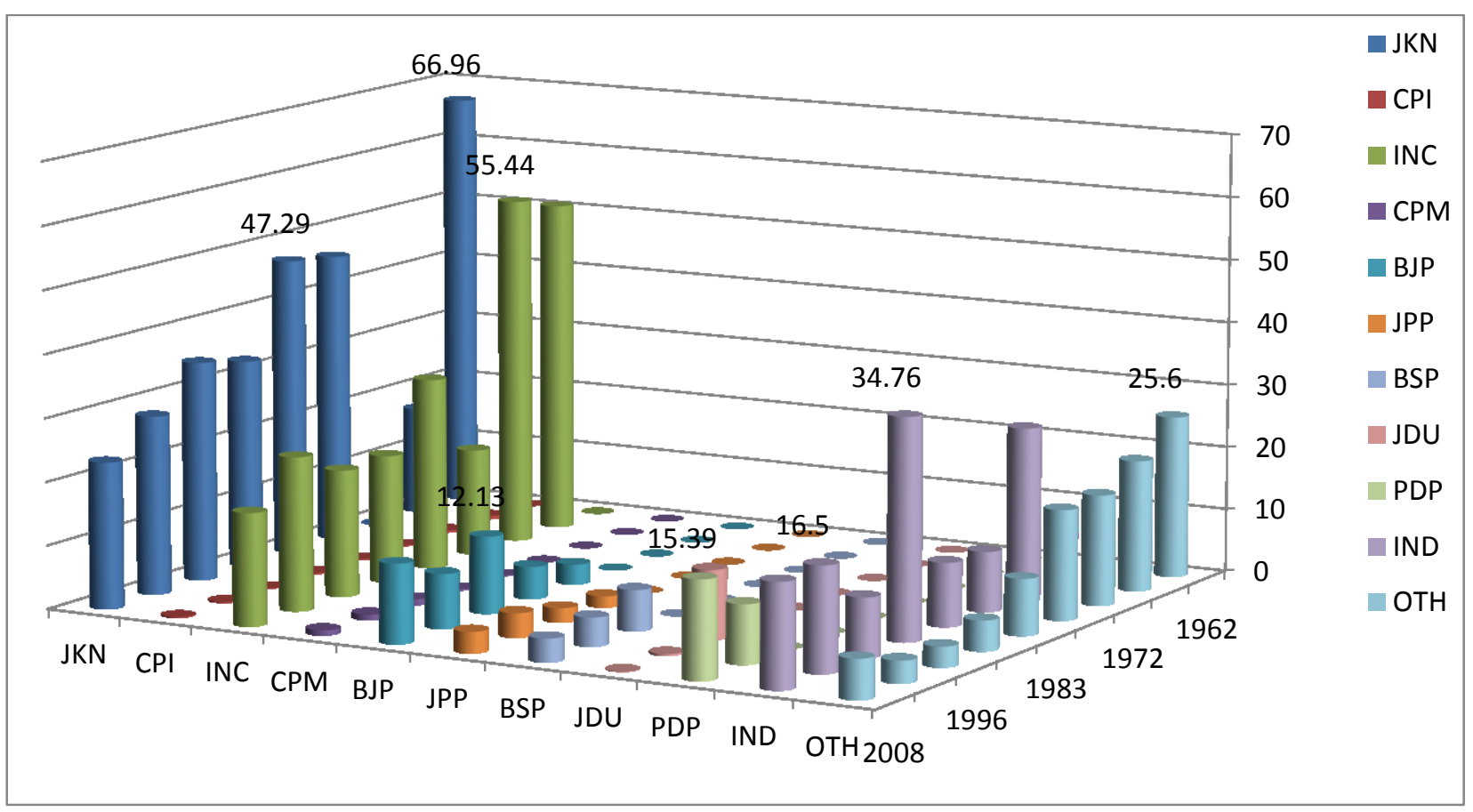

Figure 7.

Vote share percentage is equally a parameter to assess the presence of a political party among masses. The above tabulation reflects the election to election basis vote share percentage of each major political party of the region. The average vote percentage secured by these parties during all the elections under study as worked out reflects National Conference as major political party having $37.08 \%$ vote share percentage, followed by Indian National Congress with $29.72 \%$ share, Independents with $15.46 \%$ share, PDP with $12.33 \%$ share, BJP is having $8.28 \%$ share, BSP $4.86 \%$ share, JDU $3.74 \%$ and other $11.95 \%$ voter share percentage. National Conference and Indian National Congress the two major reckoned political forces having maximum vote share percentage are showing decline as we move from election to election. At the same time parties like PDP, BJP, BSP, and NPP are slow gainers.

\section{CONCLUSIONS}

Given the above analysis, one can emphatically say that democracy in the state of Jammu $\&$ Kashmir flourishes in its true colour and spirit. People of state enjoy all democratic rights like any other citizen of the country without any bias. If fact it is the people of Jammu \& Kashmir who enjoy special status under various matters ensured by Govt., of India by putting in place Article 370. Jammu \& Kashmir is a surviving democracy with no fundamental violation of any democratic or any other right.

The state of Jammu \& Kashmir is a true manifestation of democratic federal state where people elect their representative to the legislative assembly for a term of six year. Elections can also be held before the completion of full term, if the ruling party loses the vote of confidence on the floor, but this generally is the case of hung assemblies when govt., is formed with the support of allies. The state polity has grown at par with the national polity of the country in 
almost all the fronts, be it about the growth of political parties, contestants, electorate or even the polling stations for better participation of public in the electoral process.

By and large, polity of Jammu \& Kashmir has remained male dominated with minimal representation given to female candidates by both state and national political parties which more or less exposes the political hypocrisy of the country's politicians who are pressing for passing women's reservation bill but have miserably failed to give true representation to fairer sex. State political parties have most part of the democratic process of the state emerged as the ruling parties with likes like national conference, the party which has dominated over the state polity for most part. Of the late, Peoples Democratic Party has emerged as potential threat to traditional political war horse of the state National Conference.

With the unfolding of the coalition political era in the Indian democracy, absolute majority has almost become a distant dream for even leading and larger political parties. Smaller political parties along with independents most of the time prove as king makers in the Indian polity and so gets reflected in the state polity of Jammu \& Kashmir. The big question which still remains unfolded is that there are political parties who enjoy better voter percentage but have remained elusive of forming the government. So wining seats and forming govt., is altogether a different thing when it comes to vote share percentage which parties enjoy.

\section{References}

[1] Herndon, William H., Jesse W. Welk. Abraham Lincoln: The True Story of A Great Life New York: D. Appleton and Company, 1892. Vol. II., p. 65.

[2] Ministry of Home Affair's, Govt of India, New Delhi. (n.d). Retrieved August 23, 2013, from http://censusindia.gov.in/2011-prov-results/prov_results_paper1_india.html

[3] Instrument of Accession. (n.d). Instrument of accession executed by Maharaja Hari Singh on Ocober 26, 1947. Retriveved on Dec 15, 2013 from http://www.kashmirinformation.com/LegalDocs/KashmirAccession.html

[4] Ministry of Home Affair's, Govt of India, New Delhi. (n.d). Retrieved August 23, 2013, from http://censusindia.gov.in/2011-prov-results/prov_results_paper1_india.html

[5] Jammu \& Kashmir Legislative Assembly (n.d). Retrieved on January 15, 2014 from http://legislativebodiesinindia.gov.in/States/J\&K/j\&k-la-w.htm

[6] Jammu \& Kashmir Legislative Council (n.d). Retrieved on January 15, 2014 from http://www.jklegislativecouncil.nic.in/members\%20handbook/Handbook\%20for\%20M embers.pdf

[7] Shastri S. (2013). The 2013 Karnataka Assembly Outcome: Government Performance and Party Organization Matters. Studies in Indian Politics, 1(2); 135-152.

[8] MIWA, H. I. R. O. K. I. (1997). General Election in India. Political Science Annual, 185.

[9] Sharon F. Lean, Nicole Elise Gerring (2013). Liberia's 2011 General Elections. Electoral Studies. 32, 204-208.

[10] Sean Mueller., Paolo Dardanelli (2013). The parliamentary and executive elections in Switzerland, 2011. Electoral Studies. 32; 197-208.

[11] Tinker I., Walker M. (1956). The First General Elections in India and Indonesia. Far Eastern Survey, 25(7); 97-110. 
[12] Kothari R. (1967). India: The Congress System on Trial. Asian Survey, 83-96.

[13] Kaviraj S. (1997). The general elections in India. Government and Opposition, 32(1); 324.

[14] Kumar S. (2002). Reforming Indian electoral process. Economic and Political Weekly, 3489-3491.

[15] Mhatre, Minal. (2009). Women in Electoral Politics: A Case Study of Women's Political Participation in Maharashtra.

[16] Reif Karlheinz (2013). National Electoral Cycles and European Election 1979 and 1984.

[17] Paul R. Abramson, John H. Aldrich, Abraham. Diskin, Aaron M. Houck, Renan Levine F., Thomas J. Scotto (2013). The British General Elections of 2010 under different voting rules. Electoral Studies, 32; 134-139.

[18] Tim Haughton., Alenka Kra-sovec (2013). The 2011 parliamentary elections of Slovenia. Electoral Studies, 32; 201-204. 